Sains Malaysiana 49(9)(2020): 2261-2267

http://dx.doi.org/10.17576/jsm-2020-4909-23

\title{
Rice Husk Activated Carbon with NaOH Activation: Physical and Chemical Properties
}

(Karbon Teraktif Sekam Padi Diaktivasi dengan NaOH: Sifat Fizikal dan Kimia)

\author{
Mohamad Jani SaAD*, Chia Chin Hua, Suffian Misran, Sarani ZaKaria, Mohd Saiful Sajab \& \\ MOHAMMAD HARIZ ABDUL RAHMAN
}

\begin{abstract}
Activated carbon was produced from rice husk by activating with NaOH. Three types of samples were made at 850, 750, and $650^{\circ} \mathrm{C}$ activation temperature. The properties of the samples were determined. The activated carbons have surface area of $429.82 \mathrm{~m}^{2} / \mathrm{g}$ from $850{ }^{\circ} \mathrm{C}$ activation, $121.39 \mathrm{~m}^{2} / \mathrm{g}\left(750{ }^{\circ} \mathrm{C}\right)$ and $93.89 \mathrm{~m}^{2} / \mathrm{g}\left(650{ }^{\circ} \mathrm{C}\right)$. The results were higher than rice husk carbon without activation $\left(0.23 \mathrm{~m}^{2} / \mathrm{g}\right)$. The activated carbons have mesopore size (2-50 nm). Proximate and ultimate analyses of the samples were also determined. The activation process increased the carbon content of the samples. Physical characteristics of the activated carbons were shown from the XRD analysis. FTIR demonstrated the different functional of the rice husk carbon and activated. The SEM images showed the pores on the surface of the activated carbon due to the $\mathrm{NaOH}$ activation.
\end{abstract}

Keywords: Activated carbon; chemical properties; NaOH activation; physical properties; rice husk

\section{ABSTRAK}

Karbon teraktif (AC) daripada sekam padi telah dihasilkan dengan mengaktifkan NaOH. Tiga jenis sampel karbon teraktif dihasilkan pada suhu 850, 750 dan $650{ }^{\circ} \mathrm{C}$. Keputusan luas permukaan sampel sekam karbon teraktif ialah $429.82 \mathrm{~m}^{2} / \mathrm{g}\left(850{ }^{\circ} \mathrm{C}\right), 121.39 \mathrm{~m}^{2} / \mathrm{g}\left(750{ }^{\circ} \mathrm{C}\right)$ dan $93.89 \mathrm{~m}^{2} / \mathrm{g}\left(650{ }^{\circ} \mathrm{C}\right)$. Nilai ini lebih tinggi jika dibandingkan dengan sekam karbon kawalan iaitu $0.23 \mathrm{~m}^{2} / \mathrm{g}$. Saiz liang bagi karbon teraktif sekam padi ialah 2-50 $\mathrm{nm}$ iaitu dalam saiz mesoliang. Hasil analisis proksimat dan muktamad turut ditentukan. Proses pengaktifan telah meningkatkan kandungan karbon sampel. Ciri fizikal karbon teraktif ditunjukkan daripada analisis XRD. FTIR menunjukkan kefungsian berbeza karbon sekam padi dan teraktif. Pemerhatian daripada ujian SEM mendapati adanya liang-liang pada permukaan karbon teraktif hasil daripada pengaktifan $\mathrm{NaOH}$.

Kata kunci: Karbon teraktif; pengaktifan $\mathrm{NaOH}$; sekam padi; sifat fizikal; sifat kimia

\section{INTRODUCTION}

In Malaysia, more than 3 million tonnages of rice husk were generated from 685,545 hectares of paddy land in the year of 2017 (JPM 2017). Most of them were burned which creating air pollution, hence not healthy for the environment. Therefore, it will be meaningful if we can utilize the rice husk for useful products such as activated carbon (AC) which may give positive effect to the environment.

Charcoal is a carbon material from the process of carbonization and is a precursor for making AC. Due to cost constraint and dwindling of coal sources, charcoal can be produced from agricultural sources such as paddy, coconut and banana (Danish \& Ahmad 2018; Hamza et al. 2016; Kaman et al. 2017; Soltani et al. 2015).

Activated carbon is a non-graphitic-graphitizable carbon with much disordered microstructure. It has a unit of basic structural which is nearer to the graphite structure. It has high adsorption capacity from its high porosity and surface area. It usually made from the activation process of carbon materials such as coal and cellulosic sources (Park \& Oh 2002). AC mostly used in water treatment, pharmacy and medical (Abdulsalam et al. 2018; Alkhatib et al. 2015; Sharma \& Bhattacharya 2017).

The production of AC can be either by chemical or physical activation process. Physical activation process 
can be done using steam or carbon dioxide gas, whereas chemical activation using chemicals such as sodium hydroxide $(\mathrm{NaOH})$ (Schröder et al. 2007), potassium hydroxide (KOH) (Chen et al. 2008; Enaime et al. 2017; Oh \& Park 2002; Yakout et al. 2015), zinc chloride $\left(\mathrm{ZnCl}_{2}\right)$, iron oxide (Hidayu \& Muda 2016; Zainol et al. 2017) or phosphoric acid (Mopoung et al. 2015; Shamsuddin et al. 2016) prior to heating at certain temperature in an inert gas (Kalderis et al. 2008). Activated carbon obtained through chemical activation produced a larger surface area and developed better mesoporosity (Khadiran et al. 2015; Nasri et al. 2015; Viboon et al. 2008).

Alkali hydroxides, such as $\mathrm{NaOH}$ and $\mathrm{KOH}$, are usually used as agent for the activating of AC because of the good development of porosity produced by them (Foo \& Hameed 2011; Guo et al. 2003; Perrin et al. 2004). Research on rice husk AC prepared using two-steps method had been reported earlier (Chang et al. 2014). The method includes biomass carbonization followed by activation. The method makes activating agent react more with the biomass carbon resulted in higher surface area and pore volume of the AC (Basta et al. 2009).

The chemical reactions of $\mathrm{NaOH}$ and carbon during the activation process can be written as follow (Chunlan et al. 2005):

$$
\begin{aligned}
& 4 \mathrm{NaOH}+\mathrm{C} \rightarrow \mathrm{Na}_{2} \mathrm{CO}_{3}+\mathrm{Na}_{2} \mathrm{O}+2 \mathrm{H}_{2} \\
& 2 \mathrm{Na}_{2} \mathrm{O}+\mathrm{C} \rightarrow 4 \mathrm{Na}+\mathrm{CO}_{2} \\
& \mathrm{Na}_{2} \mathrm{CO}_{3}+2 \mathrm{C} \rightarrow 2 \mathrm{Na}+3 \mathrm{CO}
\end{aligned}
$$

Due to the Malaysia's rice husks ACs are less reported, therefore, in this research, rice husk AC was produced using two-steps method, i.e. carbonization followed by the activation processes. In this study, the physical and chemical properties of rice husk activated carbons prepared using two-steps method at three different activation temperature $\left(650,750\right.$, and $\left.850{ }^{\circ} \mathrm{C}\right)$ which activated for $2 \mathrm{~h}$ with $\mathrm{NaOH}$ activation agent, were determine and analyzed by elemental analyses, Fouriertransform infrared (FTIR), Brunauer-Emmett- Teller (BET), X-ray diffraction (XRD) and scanning electron microscopy (SEM).

\section{MATERIALS AND METHODS}

\section{MATERIALS}

Rice husk was obtained from a rice mill in Sekinchan, Selangor, Malaysia. The rice husk was washed from contaminants using tap water, dried under the sun and then with oven. Activating agent, sodium hydroxide $(\mathrm{NaOH})$, in granule form was purchased from Merck (M) Sdn. Bhd.

\section{CHEMICAL ACTIVATION}

The rice husk was carbonized in a closed chamber at 400 ${ }^{\circ} \mathrm{C}$ for $4 \mathrm{~h}$ for making rice husk carbon. Then, the rice husk carbon was separated from fine materials using sieve with mesh size of 60 , then impregnated with $\mathrm{NaOH}$ by soaking in the $13 \%$ solution for $24 \mathrm{~h}$ with rice husk carbon to $\mathrm{NaOH}$ ratio of $1: 4(\mathrm{w}: \mathrm{v})$. The mixture was filtered and dried in oven at $105{ }^{\circ} \mathrm{C}$ overnight. The impregnated rice husk carbon was activated in a tube furnace under nitrogen gas flow at certain temperatures $\left(650,750\right.$, and $\left.850{ }^{\circ} \mathrm{C}\right)$ for $2 \mathrm{~h}$. After that, the sample was cooled to ambient temperature and washed with hydrochloric acid solution $(1.0 \mathrm{M})$ and deionized water to get $\mathrm{pH} 6$ to 7 . The nonactivated samples were labelled as RH (rice husk) and RHC (rice husk carbon). The rice husk carbon activated at 650,750 , and $850{ }^{\circ} \mathrm{C}$ were designated as RHAC650, RHAC750, and RHAC850 (or RHACNa), respectively.

\section{PHYSICAL AND CHEMICAL ANALYSES}

The samples were analyzed for carbon, hydrogen, sulphur, and nitrogen contents using elemental analyzer (Elementar Macro Cube). Proximate analysis was conducted to determine ash content, volatile matter, and fixed carbon. The samples were analyzed with Fouriertransform infrared (FTIR) spectroscopy (Perkin Elmer 2000) to examine the functional groups in region of 500 to $4000 \mathrm{~cm}^{-1}$. The nitrogen adsorption-desorption analysis (Micromeritics ASAP 2010) was used to study the surface area and porosity. The X-ray diffraction (XRD) analysis was conducted with Bruker AXS D8 Advance in order to study the crystallinity of the samples. The morphology observations of the samples were done using scanning electron microscopy (SEM), FEI Quanta 400.

\section{RESULTS AND DISCUSSION}

The results of proximate and ultimate analyses of the $\mathrm{RH}, \mathrm{RHC}$ and RHACNa are tabulated in Table 1. There are increasing in percentage of fixed carbon and reducing of ash content and volatile matter after the rice husk was activated. The RSACNa sample showed high percentage of carbon and low hydrogen, Sulphur, and nitrogen contents. The use of $\mathrm{NaOH}$ had enhanced the chemical activation of the material. The percentage of carbon content increased due to the carbonization and activation processes (Mohd Iqbaldin et al. 2013; Rhaman et al. 2015).

The FTIR spectra of the RH, RHC and RHACNa samples are shown in Figure 1. The RH and RHC spectra were more intense as compared to the RHACNa at $3100-3600 \mathrm{~cm}^{-1}$. The RHACNa was less intense could be due to less prevalent $\mathrm{OH}$ stretching as the results of the carbonization and activation processes. As such, the aromatic structure was developed (Oh et al. 2003). The same pattern also displayed from the absorbance at 1043 $\mathrm{cm}^{-1}$ from $\mathrm{OH}$ bending (San Miguel et al. 2003). The 
absorbance at $3425 \mathrm{~cm}^{-1}$ can be assigned to absorbed water or O-H stretching of OH groups (Guo \& Rockstraw 2007). Weak band observed at $2800-2900 \mathrm{~cm}^{-1}$ of the RH and RHC spectra, indicating stretching vibrations of the $\mathrm{C}-\mathrm{H}$ bonds of the methylene groups $\left(-\mathrm{CH}_{2}-\right)$ (Cazetta et al. 2011). However, the bands were not seen in RHACNa sample. It could be due to the deformation of the $\mathrm{C}-\mathrm{H}$ bonds to create an aromatic $\mathrm{C}=\mathrm{C}$ bond at the higher activation temperature (Zhu et al. 2012). The absorbance between 700 and $1200 \mathrm{~cm}^{-1}$ related to aromatic which is out of plane $\mathrm{C}-\mathrm{H}$ bending with different type of substitutions.

TABLE 1. Proximate and ultimate analyses results

\begin{tabular}{lccc}
\hline \multicolumn{1}{c}{ Type of analysis } & RH & $\begin{array}{c}\text { Samples } \\
\text { RHC }\end{array}$ & RHACNa \\
\hline Proximate & & & 13.09 \\
Ash content (\%) & 30.04 & 19.11 & 7.47 \\
Volatile matter (\%) & 63.32 & 14.06 & 78.63 \\
Fixed carbon (\%) & 6.64 & 66.83 & 69.02 \\
Ultimate & & & 4.70 \\
Carbon (\%) & 39.63 & 55.08 & 0.21 \\
Hydrogen (\%) & 4.39 & 7.83 & 0.34 \\
Sulphur (\%) & 0.021 & 0.045 & 0.51 \\
Nitrogen (\%) & 0.46 & & \\
\hline
\end{tabular}

The spectra showed no $\mathrm{SiO}_{2}$ peaks at 1101, 944, and $789 \mathrm{~cm}^{-1}$ (An et al. 2011). The absorbance at $1380 \mathrm{~cm}^{-1}$ is attributed from the deformation of aliphatic of $\mathrm{CH}_{2}$ or $\mathrm{CH}_{3}$ groups or bending of the $\mathrm{O}-\mathrm{H}$ of phenolic- $\mathrm{OH}$.
The band was weaker in AC sample, which is due to the aromatization and dehydration from the condensation and decomposition of volatile matter (Wu et al. 2012).

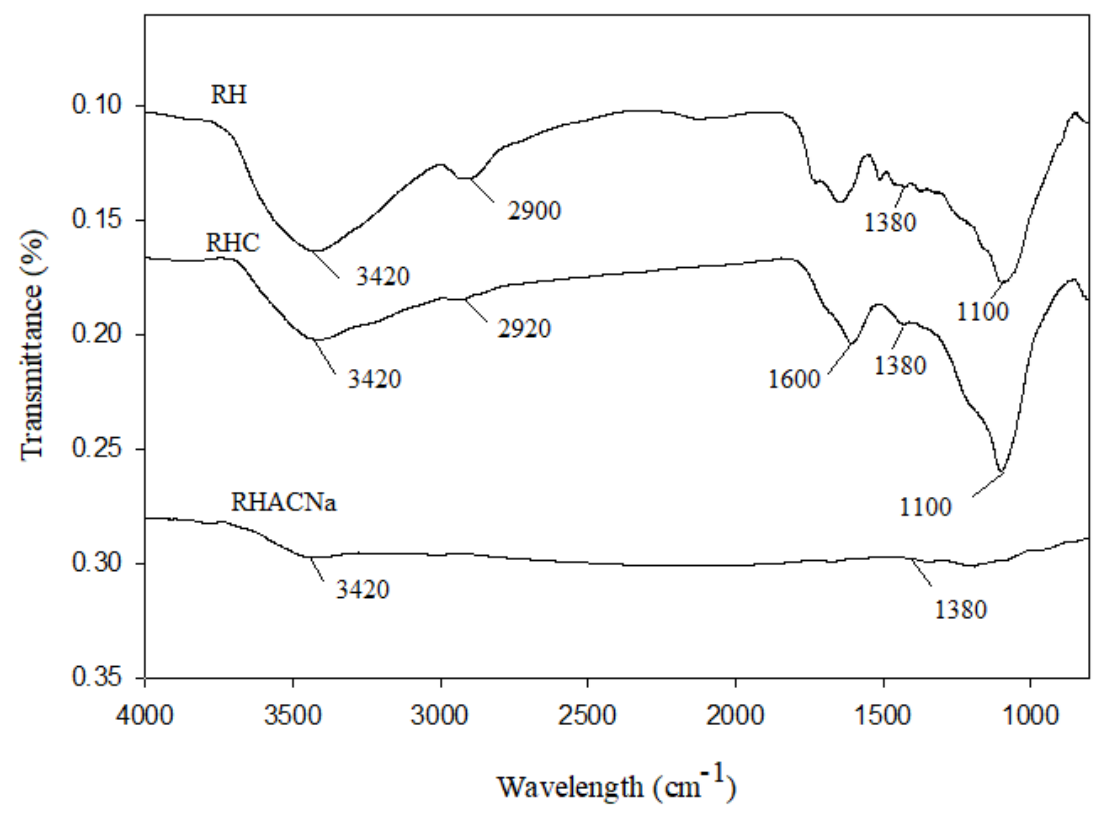

FIGURE 1. FTIR spectra of RH, RHC and RHACNa 
The porosity characteristics i.e. total pore volume $\left(\mathrm{V}_{\text {total }}\right)$, pore sizes and surface area $\left(\mathrm{S}_{\mathrm{BET}}\right)$ of RHC and RHACNa from the nitrogen adsorption-desorption test using BET model are demonstrated in Table 2. The surface area of RHC is $0.23 \mathrm{~m}^{2} / \mathrm{g}$ which much lower than the RHACNa as results of the activation process. The surface area of rice husk carbon activated at $850^{\circ} \mathrm{C}$ was highest $\left(429.82 \mathrm{~m}^{2} / \mathrm{g}\right)$ as compared to $750{ }^{\circ} \mathrm{C}\left(121.39 \mathrm{~m}^{2} / \mathrm{g}\right)$ and $650{ }^{\circ} \mathrm{C}(93.89$ $\mathrm{m}^{2} / \mathrm{g}$ ). The process temperature has favorable impact to the pores development. It could be because of the influence of volumetric widening of the pores and heat-induced internal (Foo \& Hameed 2012). The volatile component released at the time of heat activation process resulted in the improvement of BET surface area. The reducing of $\mathrm{NaOH}$ into metal Na probably performed during the process of activation (Eq. 1, 2, and 3). Na was diffused into the surfaces of carbon at the boiling point temperature and pores created in the structure of carbon which increasing the surface area (Rostamian et al. 2015). The RHACNa's total pore volume $\left(\mathrm{V}_{\text {total }}\right)$ increased with activation temperature in which the value varies from 0.12 to 0.29 $\mathrm{cm}^{3} / \mathrm{g}$ and mostly contributed by pore area. Increasing in surface area resulted to the increase of mesopore volume (Viboon et al. 2008).

TABLE 2. Porosity properties of the RHC and RHAC

\begin{tabular}{lcccc}
\hline \multicolumn{1}{r}{ Property } & RHC & RHAC650 & RHAC750 & RHAC850 \\
\hline $\mathrm{S}_{\mathrm{BET}}\left(\mathrm{m}^{2} / \mathrm{g}\right)$ & 0.23 & 93.89 & 121.39 & 429.82 \\
$\mathrm{~V}_{\text {total }}\left(\mathrm{cm}^{3} / \mathrm{g}\right)$ & 0.0026 & 0.12 & 0.13 & 0.29 \\
Average pore size $(\mathrm{nm})$ & 4.42 & 5.03 & 4.19 & 2.69 \\
\hline
\end{tabular}

Average pore size of RHC and activated varies from 2.69 to $5.03 \mathrm{~nm}$ and fall in the mesopore size $(2-50 \mathrm{~nm})$. According to the IUPAC (1972), there are three pore sizes namely micropore (less than $2 \mathrm{~nm}$ ), mesopore $(2-50 \mathrm{~nm}$ ) and macropore (more than $50 \mathrm{~nm}$ ) (Lu et al. 2015). The pore size of the activated carbon is important due to its effect on the properties whenever used in the adsorption study. The adsorption ability of the activated carbon towards the adsorbates mostly influenced by the activated carbon's pore size. For example, the mesopore size suitable used for adsorption on water pollutants (Sobhy et al. 2015).
XRD diagram of the RHC and RHACNa are shown in Figure 2. It exhibits broad peaks in the range of 20 to $30^{\circ}$. They indicate the existence of amorphous silica (Puziy et al. 2002). The RHACNa showed two broad peaks at 20-30 and $40-50^{\circ}$ which related to the existence of more amorphous carbon (Shamsuddin et al. 2016). During the activation, pores were created and crystal structure was disappeared (Ma \& Ouyang 2013). The activated carbon made of graphite-like micro-crystallites was bounded by cross linking network including some graphite-like layer (Srenscek-Nazzal et al. 2013).

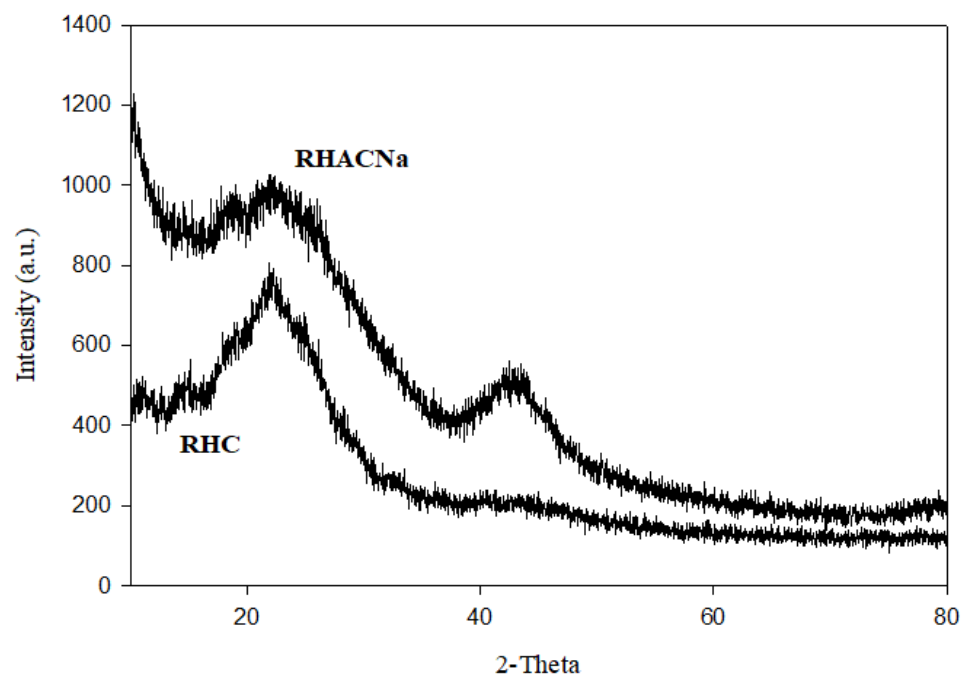

FIGURE 2. Results of XRD for RHC and RHACNa 
Figure 3(a) shows SEM micrograph of the RHC with no pores. Developed pores can be found on the surfaces of RHACNa which could be due to the $\mathrm{NaOH}$ activation as shown in Figure 3(b). The $\mathrm{NaOH}$ activation occurred in structure porous of carbon which created the pores (Pandey et al. 2015). The large pores produced high surface area as reported. The findings are similar with studies by Oh et al. (2003) and Oh and Park (2002).
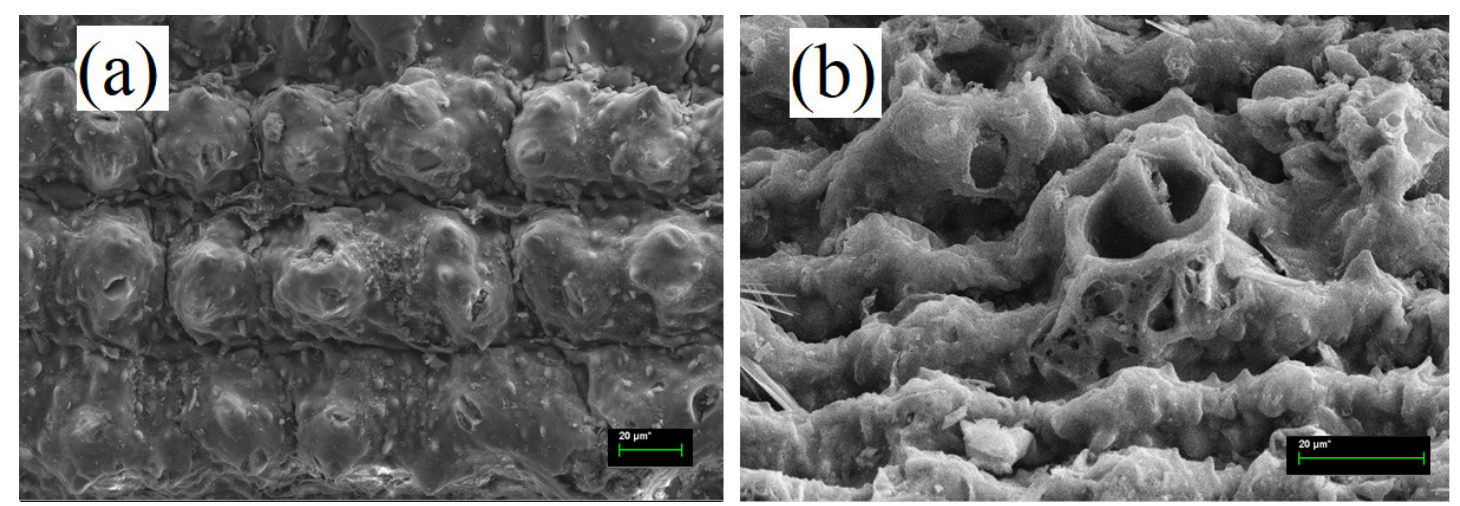

FIGURE 3. SEM of RHC (a) and RHACNa (b) at magnification of $500-1000 \times$

\section{CONCLUSION}

The $\mathrm{NaOH}$ activation affected the properties of rice husk activated carbon. It reduced the ash content and volatile matter and increased the fixed carbon and carbon content. Some functional groups of the activated carbon were differed than the RH and RHC. Surface area and pore volume increased due the activation process and gradually increased as the activation temperature increased. The rice husk activated carbon attained highest surface area $\left(429.82 \mathrm{~m}^{2} / \mathrm{g}\right)$ at $850^{\circ} \mathrm{C}$ temperature. The pore sizes of the activated carbons were in mesopore sizes. Graphite-like micro-crystallites was observed on RHACNa from the $\mathrm{XRD}$ analysis. The surface of the RHACNa was porous as shown from the SEM image.

\section{ACKNOWLEDGEMENTS}

This work was financially supported by the Malaysian Agricultural Research and Development Institute (MARDI), Malaysia. Thanks to the staff of UKM, FRIM and MARDI who have gave assistance during the sample preparation and analysis works.

\section{REFERENCES}

Abdulsalam, M., Hasfalina, C.M., Mohamed, H.A., Abd Karim, S.F. \& Faiez, M.S. 2018. Microwave irradiated coconut shell-activated carbon for decolourisation of palm oil mill effluent (POME). Food Research 2(6): 526-534.

Alkhatib, M.F., Mamun, A.A. \& Akbar, I. 2015. Application of response surface methodology (RSM) for optimization of color removal from POME by granular activated carbon. International Journal of Environmental Science and Technology 12(4): 1295-1302.

An, D., Guo, Y., Zou, B., Zhu, Y. \& Wang, Z. 2011. A study on the consecutive preparation of silica powders and active carbon from rice husk ash. Biomass Bioenergy 35: 1227-1234.

Basta, A.H., Fierro, V., El-Saied, H. \& Celzard, A. 2009. 2-steps $\mathrm{KOH}$ activation of rice straw: An efficient method for preparing high-performance activated carbons. Bioresource Technology 100: 3941-3947.

Cazetta, A.L., Vargas, A.M.M., Nogami, E.M., Kunita, M.H., Guilherme, M.R., Martins, A.C., Silva, T.L., Moraes, C.G. \& Almeida, V.C. 2011. NaOH-activated carbon of high surface area produced from coconut shell: Kinetics and equilibrium studies from the methylene blue adsorption. Chemical Engineering Journal 174: 117-125.

Chang, K.L., Chen, C.C., Lin, J.H., Hsien, J.F., Hsien, Wang, Y., Zhao, F., Shih, Y.H., Xing, Z.J. \& Chen, S.T. 2014. Rice straw-derived activated carbons for the removal of carbofuran from an aqueous solution. New Carbon Material 29: 47-54.

Chen, J.S., Zhang, F. \& Li, G.D. 2008. Effects of raw material texture and activation manner on surface area of porous carbons derived from biomass resources. Journal of Colloid and Interface Science 327: 108-114.

Chunlan, L., Shaoping, X., Yixiong, G., Shuqin, L. \& Changhou, L. 2005. Effect of pre-carbonization of petroleum cokes on chemical activation process with KOH. Carbon 43: 22952301.

Danish, M. \& Ahmad, T. 2018. A review on utilization of wood biomass as a sustainable precursor for activated carbon 
production and application. Renewable and Sustainable Energy Reviews 87: 1-21.

Enaime, G., Ennaciri, K., Ounas, A., Bacaoui, A., Seffen, M., Selmi, T. \& Yaacoubi, A. 2017. Preparation and characterization of activated carbon from olive wastes by physical and chemical activation: Application to indigo carmine adsorption. J. Mater. Environ. Sci. 11: 4125-4137.

Foo, K.Y. \& Hameed, B.H. 2011.Utilization of rice husks as a feed stock for preparation of activated carbon by microwave induced $\mathrm{KOH}$ and $\mathrm{K}_{2} \mathrm{CO}_{3}$ activation. Bioresources Technology 102: 9814-9817.

Foo, K.Y. \& Hameed, B.H. 2012. Adsorption characteristics of industrial solid waste derived activated carbon prepared by microwave heating for methylene blue. Fuel Processing Technology 99: 103-109.

Guo, Y.P. \& Rockstraw, D.A. 2007. Activated carbons prepared from rice hull by one-step phosphoric acid activation. Microporous and Mesoporous Materials 100: 12-19.

Guo, Y.P., Yang, S.F., Fu, W.Y., Qi, J.R., Li, R.Z., Wang, Z.C. \& $\mathrm{Xu}$, H.D. 2003. Adsorption of malachite green on micro- and mesoporous rice husk-based active carbon. Dyes Pigments 56: $219-229$

Hamza, U.D., Nasri, N.S., Amin, N.A.S., Mohammed, J. \& Zain, H.M. 2016. Characteristics of oil palm shell biochar and activated carbon prepared at different carbonization times. Desalination and Water Treatment 57(17): 7999-8006.

Hidayu, A.R. \& Muda, N. 2016. Preparation and characterization of impregnated activated carbon from palm kernel shell and coconut shell for $\mathrm{CO}_{2}$ capture. Procedia Engineering 148: 106-113.

International Union of Pure and Applied Chemistry (IUPAC) 1972. IUPAC Manual of Symbols and Terminology Appendix 2, Pt. 1. Colloid and Surface Chemistry. Pure and Applied Chemistry 31(4): 578-638.

Jabatan Pertanian Malaysia (JPM). 2017. Lapuran Keluasan Tanaman dan Keluaran Padi dan Beras Seluruh Malaysia. Jabatan Pertanian Malaysia. Accessed on 10 June 2019.

Kalderis, D., Koutoulakis, D., Paraskeva, P., Diamadopoulos, E., Otal, E., del Valle, J.O. \& Fernandez-Pereira, C. 2008. Adsorption of polluting substances on activated carbons prepared from rice husk and sugarcane bagasse. Chemical Engineering Journal 144: 42-50.

Kaman, S.P.D., Tan, I.A.W. \& Lim, L.L.P. 2017. Palm oil mill effluent treatment using coconut shell - based activated carbon: Adsorption equilibrium and isotherm. MATEC Web of Conferences 87: 03009.

Khadiran, T., Hussein, M.Z., Zainal, Z. \& Rusli, R. 2015. Textural and chemical properties of activated carbon prepared from tropical peat soil by chemical activation method. BioResources 10: 986-1007.

Lu, C., Pan, L. \& Zhu, B. 2015. Study the static adsorption/ desorption of formaldehyde on activated carbon. International Forum on Energy, Environment Science and Materials (IFEESM 2015). pp. 943-947.

Ma, X. \& Ouyang, F. 2013. Adsorption properties of biomassbased activated carbon prepared with spent coffee grounds and pomelo skin by phosphoric acid activation. Applied Surface Science 268: 566-570.
Mohd Iqbaldin, M.N., Khudzir, I., Mohd Azlan, M.I., Zaidi, A.G., Surani, B. \& Zubri, Z. 2013. Properties of coconut shell activated carbon. Journal of Tropical Forest Science 25(4): 497-503.

Mopoung, S., Inkum, S. \& Anuwetch, L. 2015. Effect of temperature on micropore of activated carbon from sticky rice straw by $\mathrm{H}_{3} \mathrm{PO}_{4}$ activation. Carbon - Science and Technology 7(3): 24-29.

Nasri, N.S., Basri, H. \& Garba, A. 2015. Synthesis and characterization of low cost-porous carbon from palm oil shell via $\mathrm{K}_{2} \mathrm{CO}_{3}$ chemical activation process. Applied Mechanics and Materials 735: 36-40.

Oh, G.H. \& Park, C.R. 2002. Preparation and characteristics of rice straw based porous carbon with high adsorption capacity. Fuel 81: 327-336.

Oh, G.H., Yun, C.H. \& Park, C.R. 2003. Role of $\mathrm{KOH}$ in the one-stage $\mathrm{KOH}$ activation of cellulosic biomass. Carbon Science 4: 180-184.

Pandey, B.D., Saima, H.K. \& Chattree, A. 2015. Preparation and characterization of activated carbon derived from rice husk by $\mathrm{NaOH}$ activation. International Journal of Mathematics and Physical Sciences Research 3(2): 158-164.

Park, C.R. \& Oh, G.H. 2002. Preparation and characteristics of rice straw based porous carbon with high absorption capacity. Fuel 81: 327-336.

Perrin, A., Celzard, A., Albiniak, A., Kaczmarczyk, J., Mareche, J.F. \& Furdin, G. 2004. NaOH activation of anthracites: Effect of temperature on pore textures and methane storage ability. Carbon 42: 2855-2901.

Puziy, A.M., Poddubnaya, O.I., Martinez-Alonso, A., SuárezGarcia, F. \& Tascón, J.M.D. 2002. Synthetic carbons activated with phosphoric acid I. Surface chemistry and ion binding properties. Carbon 40: 1493-1505.

Rhaman, M., Haque, M., Rouf, M., Siddique, M. \& Islam, M. 2015. Preparation and characterization of activated carbon $\&$ amorphous silica from rice husk. Bangladesh Journal of Scientific and Industrial Research 50(4): 263-270.

Rostamian, R., Heidarpour, M., Mousavi, S.F. \& Afyuni, M. 2015. Characterization and sodium sorption capacity of biochar and activated carbon prepared from rice husk. Journal Agricultural Science Technology 17: 1057-1069.

San Miguel, G., Fowler, G.D. \& Sollars, C.J. 2003. A study of the characteristics of activated carbons produced by steam and carbon dioxide activation of waste tyre rubber. Carbon 41: 1009-1016.

Schröder, E., Thomauske, K., Weber, C., Hornung, A. \& Tumiatti, V. 2007. Experiments on the generation of activated carbon from biomass. Journal of Analytical and Applied Pyrolysis 79(1-2 SPEC. ISS.): 106-111.

Shamsuddin, M.S., Yusoff, N.R.N. \& Sulaiman, M.A. 2016 Synthesis and characterization of activated carbon produced from kenaf core fiber using $\mathrm{H}_{3} \mathrm{PO}_{4}$ activation. Procedia Chemistry 19: 558-565.

Sharma, S. \& Bhattacharya, A. 2017. Drinking water contamination and treatment techniques. Applied Water Science 7(3): 1043-1067.

Sobhy, M.Y., Hakim, A.E., Daifullah, M. \& Sohair, A.E. 2015. Pore structure characterization of chemically 
modified biochar derived from rice straw. Environmental Engineering and Management Journal 14(2): 473-480.

Soltani, N., Bahrami, A., Pech-Canul, M.I. \& González, L.A. 2015. Review on the physicochemical treatments of rice husk for production of advanced materials. Chemical Engineering Journal 264: 899-935.

Srenscek-Nazzal, J., Kaminskaa, W., Michalkiewicza, B. \& Korenb, Z. 2013. Production, characterization and methane storage potential of $\mathrm{KOH}-a c t i v a t e d$ carbon from sugarcane molasses. Industrial Crops and Products 47: 153-159.

Viboon, S., Chiravoot, P., Duangdao A. \& Duangduen, A. 2008. Preparation and characterization of activated carbon from the pyrolysis of physic nut (Jatropha curcas L.) waste. Energy and Fuels 22: 31-37.

Wu, W., Yang, M., Feng, Q., McGrouther, K., Wang, H., Lu, H.H. \& Chen, Y.X. 2012. Chemical characterizations of rice straw-derived bio char for soil amendment. Biomass Bioenergy 47: 268-276.

Yakout, S.M., El Hakim Daifullah, A.M. \& El-Reefy, S.A. 2015. Pore structure characterization of chemically modified biochar derived from rice straw. Environmental Engineering and Management 14(2): 473-480.

Zainol, M.M., Amin, N.A.S. \& Asmadi, M. 2017. Preparation and characterization of impregnated magnetic particles on oil palm frond activated carbon for metal ions removal. Sains Malaysiana 46(5): 773-782.

Zhu, K., Fu, H., Zhang, J., Ly, X., Tang, J. \& Xu, X. 2012. Studies on removal of $\mathrm{NH}_{4}^{+}-\mathrm{N}$ from aqueous solution by using the activated carbons derived from rice husk. Biomass Bioenergy 43: 18-25.
Mohamad Jani Saad*, Chia Chin Hua \& Sarani Zakaria

Bioresources and Biorefinery Laboratory

Materials Science Program

Faculty of Science and Technology

Universiti Kebangsaan Malaysia

43600 UKM Bangi, Selangor Darul Ehsan

Malaysia

Mohd Shaiful Sajab

Research Centre for Sustainable Process Technology

Faculty of Engineering and Built Environment

Universiti Kebangsaan Malaysia

43600 UKM Bangi, Selangor Darul Ehsan

Malaysia

Sufian Misran

Forest Research Institute of Malaysia (FRIM)

52100 Kepong, Kuala Lumpur, Federal Territory

Malaysia

Mohamad Jani Saad* \& Mohammad Hariz Abdul Rahman Malaysian Agriculture Research and Development Institute (MARDI)

43400 Serdang, Selangor Darul Ehsan

Malaysia

*Corresponding author; email: mohamadjanisaad72@gmail.com

Received: 15 October 2019

Accepted: 8 May 2020 